\title{
The role of the pharmacist and pharmacy assistant as opinion leaders in the decision to purchase health and beauty aid products
}

\author{
R.S. Suttner, G.E. Staude and J. Viljoen \\ Rhodes University, P.O. Box 94, Grahamstown, 6140 Republic of South Africa
}

Accepted 1 October 1987

\begin{abstract}
The authors investigate opinion leadership at the retail pharmacy level with regard to the purchase of health and beauty aid products. The characteristics of opinion leaders are identified and both pharmacists and pharmacy assistants are assessed in terms of these characteristics. The proposition that both the pharmacist and the pharmacy assistant qualify as opinion leaders is confirmed using a sample of 251 white, female consumers of health and beauty aid products. The implications of this finding for both pharmacy retailers and the manufacturers/marketers of health and beauty aid products are discussed.

Die outeurs ondersoek 'opinieleiding' by die aankoop van gesondheids- en skoonheidsprodukte in die kleinhandel-aptekerswese. Die eienskappe van opinieleiers word geïdentifiseer en beide aptekers en aptekersassistente word gemeet aan hierdie eienskappe. Die stelling dat beide die apteker en sy assistent as opinieleiers kwalifiseer, word bevestig volgens 'n steekproef van 251 blanke vroue wat gebruikers is van gesondheids- en skoonheidsprodukte. Die implikasies van die bevindinge vir beide die kleinhandel-apteker en vervaardigers/bemarkers van gesondheids- en skoonheidsprodukte word bespreek.
\end{abstract}

* To whom correspondence should be addressed

\section{Introduction}

There is broad agreement that, on their way to purchasing goods and services, consumers typically pass through a number of decision stages (Engel, Blackwell \& Kollat, 1978; Walters \& Paul, 1970; Sternthal \& Craig, 1982; Zaltman \& Wallendorf, 1983; Foxall 1980). These stages may be identified as problem recognition, information search, evaluation of alternatives, choice, and post-purchase outcomes. This paper focuses upon the information search stage of the purchase process.

\section{Information search}

Once a consumer has experienced a state of tension arising out of his having recognized a problem, he immediately begins to search his environment for means of eliminating or at least reducing that state of tension. In addition, information search can also take place at the outcome stage of the purchase process, whereby if the consumer experiences post-purchase dissonance, a search for information takes place in an attempt to confirm the wisdom of the original product choice.

There tend to be two broad sources of purchase information for consumers, namely internal and external. It is logical for a consumer to start with an internal search. This comprises a largely subconscious review of past purchase and product performance experiences, as well as a review of beliefs and attitudes which have been built up over time. If there is insufficient information from internal sources, an external search is made. The consumer is exposed to a variety of external informational inputs from both personal and non-personal sources. The most significant of the non-personal external sources of information are advertising and publicity, whereas the most significant of the personal external sources of information are salesmen and opinion leaders.
To the extent that purchase behaviour involves risk in the sense that any action of a consumer will produce consequences which he cannot anticipate with any certainty, the information search stage of the purchase process takes on added importance. This risk may be financial, physical, psycho-social or performance based.

As Loudon \& Della Bitta (1979: 466) state, 'the risk involved in a purchase decision is perceived by the consumer and may or may not bear a strong relationship to what actually exists'. One of the major roles performed by opinion leaders, an external personal source of information, is the reduction of perceived risk on the part of consumers. Ross (1975: 1) concurs by stating that 'engaging in word-of-mouth communication about a product is an important way of reducing risk'.

To enable optimal structuring of its marketing communications programme, it is incumbent on any marketing organization to be sensitive to the dynamics of the information search stage of the purchase process. Information via the mass media is directed at opinion leaders who process the information, interpret it and pass it on to some consumers. These consumers also receive information directly from the mass media, as well as from non-opinion leaders known to them. Inevitably, there is an exchange of information between consumers and often a request from consumers to opinion leaders for more information. The role of opinion leaders in the information search process may therefore be a very important one.

\section{The opinion leader: In search of a definition}

Engel, et al. (1978: 282) define opinion leadership as follows: 'Opinion leadership refers to the degree to which an individual influences others in a given choice situation. Those who exert a disproportionately large amount of influence are called "opinion leaders" in those 
situations in which they exert influence'.

Kassarjian \& Robertson (1973: 294) describe the opinion leader as 'the individual within a group to whom others turn for information and advice'. This is supported by Schiffman \& Kanuk (1978: 262) who further note than an opinion leader's influence may be felt regardless of whether it is actively sought: 'Opinion leadership is the process by which one person (the opinion leader) informally influences the actions and attitudes of others who may be opinion seekers or merely opinion recipients'.

Glock \& Nicosia (1983: 24) stress the social perspective of opinion leadership: 'Opinion leaders act not only as channels of information but also as a source of social pressure toward a particular choice, and of social support to re-inforce that choice once it has been made'.

Thus, the opinion leader not only functions as a source of information at the 'information search' stage of the purchase process, but also at the 'outcome' stage where the consumer seeks information in order to overcome post-purchase dissonance.

\section{Characteristics of opinion leaders}

Having approached a definition of an opinion leader and of the nature of opinion leadership, it is necessary to attempt to identify the specific characteristics of opinion leaders. An awareness of these characteristics may be of great value to the marketer in identifying opinion leaders as agents for influencing his consumers. The purpose of this study is to determine to what extent pharmacists and pharmacy assistants are perceived to be opinion leaders by the purchasers of health and beauty aid products and therefore the extent to which they should be the focus of attention of the marketers of such products.

The following are generally accepted characteristics of opinion leaders.

\section{Social standing and group belonging}

a. The opinion leader is likely to be part of the general group that he influences but will be at a higher social status.

b. He will tend to have more social participation than his followers.

c. He will be more norm abiding and more loyal to group standards and values.

d. He will be more cosmopolitan than his followers, that is, more oriented beyond the community of the group.

e. He will be a person who closely personifies the group's values and norms and is likely to have greater empathy with members of the group which he influences.

f. He will be a person with greater organizational membership and participation and will have greater participation in formal and informal social activities than non-leaders.

When the pharmacist and pharmacy assistant are assessed against the social standing and group belonging characteristic of opinion leadership, the following conclusions may be drawn.

\section{The pharmacist}

On prima facie evidence the pharmacist appears to satisfy most of the characteristics under this heading as he is likely to be part of the general group of 'health care advisors' such as doctors, dentists and para-medics, and in addition he is likely to have a higher social status because of his professional qualifications. Because most pharmacists belong to at least one formal pharmaceutical organization, such as the Pharmaceutical Society of South Africa, they have the opportunity at least to have greater participation in formal organizations.

Whether the pharmacist will more closely personify the group's values, and whether he will be norm abiding or not, are however, on the basis of limited knowledge and evidence, more difficult to determine.

\section{The pharmacy assistant}

The position of the pharmacy assistant as opinion leader is not as clear cut as that of the pharmacist.

There is no evidence to show that the pharmacy assistant is likely to exhibit any of the characteristics under the heading of social standing and group belonging. It is reasonable to assume, however, that the pharmacy assistant will have the same demographic profile as the average for the customers of the pharmacy.

\section{Knowledge and Interest}

a. Generally, opinion leaders will have a greater interest in and knowledge of the area of influence. In the same way, an individual who is very knowledgeable about a topic valued by the group will probably be an opinion leader. An opinion leader's knowledge is of particular value with regard to those products with which a large amount of perceived risk, whether economic, social or physical, is associated. For those products with which little or no perceived risk is associated, consumers may not go to the trouble of interacting with opinion leaders but may simply rely on information gleaned from non-personal sources.

b. The opinion leader will have a higher degree of self involvement in his subject than his followers and will thus be a more avid reader of material on related issues. The opinion leader will also be more knowledgeable about related new product development.

c. A formal, academic qualification in a particular subject will enhance an individual's role as an opinion leader in that subject.

d. Opinion leaders have greater exposure to mass media than non-leaders. This is especially true when relevant to their own area of competence or interest. At the same time, the opinion leader tends to use more impersonal, technically accurate and widespread sources of information than do his followers.

When the pharmacist and pharmacy assistant are assessed in terms of the 'knowledge and interest' characteristic of an opinion leader, the following conclusions may be drawn: 


\section{The pharmacist}

The pharmacist again clearly qualifies as an opinion leader as he undoubtedly would have a greater interest in and knowledge of the area of influence. Similarly, the pharmacist would have a high degree of self-involvement in his subject and would likely be an avid reader of specialist pharmaceutical media. His academic qualification obviously adds to the weight of opinion leadership and although no comment can be made about his exposure to mass media, a safe assumption would be that he would tend to use more impersonal, technically accurate sources of information by virtue of the nature of his business.

The conclusion is that the pharmacist qualifies easily as an opinion leader which is further confirmed by Hawkins, et al. (1983: 223): 'For some product categories, there are professional opinion leaders ... Pharmacists are important opinion leaders for a wide range of health care products'.

In addition Nel (1982: 160) in her study using respondents in the Western Cape Area found that: 'they (the consumers) consider that the benefits of shopping at their community pharmacist are: Expert advice, wide range of merchandise, convenience and an hygienic, clean and hassle-free atmosphere'.

\section{The pharmacy assistant}

Here again a conclusion is difficult. It is, however, reasonable to assume that the pharmacy assistant by virtue of her position might be perceived to have a greater interest and knowledge in the area in which she works.

The pharmacy assistant will not normally hold any academic qualification in pharmaceutics and no conclusion can be drawn regarding her exposure to mass media or subject-specific material.

\section{Personality traits}

It is generally accepted that the following personality traits tend to be characteristic of opinion leaders:

a. Opinion leaders tend to be more gregarious than nonleaders and accordingly, people find it easy to relate to opinion leaders.

b. Opinion leaders have been found to be more emotionally stable, assertive and likeable. They are also less depressive or self-deprecating and tend to be more self-confident.

c. Opinion leaders have a positive self-image insofar as they perceive themselves as more interested in the area for which they are opinion leaders than nonleaders.

This is a difficult area for generalization for either pharmacists or pharmacy assistants and the only conclusion is that by the nature of their occupation, the success of their business will depend to a great extent on the relationship between them and their customers. The consumer is more likely to heed the advice of someone with whom he has a good relationship.

\section{Innovation}

a. Opinion leaders tend to have more favourable attitudes toward both new products as a concept and new products within their specific area of influence.

b. As a result, opinion leaders will be more likely to try new products than non-leaders and will reflect greater commitment to trying new products than non-leaders. Here again, a similar conclusion can be drawn for both the pharmacist and pharmacy assistant. They are both likely to have an interest in, and hopefully a favourable attitude towards new products and concepts in their field. The pharmacist would have this attitude because of the potential benefit to his or her business and the pharmacy assistant because of the nature of his or her tasks. This is also important because of the number of possible queries about new products from potential customers.

\section{Availability and information flow}

a. An individual who is available and readily accessible and active in the interpersonal communications process will have a better chance for a leadership position.

b. By being available, the opinion leader creates the opportunity for a flow of information and influence to and from himself. For this communication to take place and for the person in question to qualify as an opinion leader, one or more of the following characteristics will apply:

- non-leaders will normally ask for advice from the opinion leader about the subject in question;

- the opinion leader will be accustomed to spontaneously giving advice on the subject in question without asking or prompting;

- non-leaders will usually heed the advice of the opinion leader;

- non-leaders will usually spontaneously pass on the advice of the opinion leaders to other 'non-leader' friends or acquaintances; and,

- the opinion leader will always, or most often, be the logical problem solver for the subject in question for the non-leader.

When the pharmacist and pharmacy assistant are assessed in terms of the availability and information flow characteristic of opinion leaders, the following conclusions may be drawn.

\section{The pharmacist}

Clearly, the pharmacist as health care professional is more readily available to the public than is a doctor, for example. In addition, the pharmacist's services as advisor are free. By being available, the pharmacist creates the opportunity for the flow of information to the consumer. He is positioned as a 'junior doctor'.

No conclusion can be drawn, however, on the extent to which the pharmacist's advice is sought, heeded and passed on. 


\section{The pharmacy assistant}

The pharmacy assistant is also readily available to the general public but here doubt exists as to the extent to which the general public will heed advice given by the pharmacy assistant.

\section{The study}

Against the background of the role and characteristics of opinion leaders, the objectives of this study were twofold:

(i) To establish whether white, female consumers within the Johannesburg metropolitan area, perceive the pharmacist to be an opinion leader for purchases of health and beauty aid products.

(ii) To establish whether white, female consumers within the Johannesburg metropolitan area, perceive the pharmacy assistant to be an opinion leader for the purchases of health and beauty aid products.

In determining whether the pharmacist is perceived as an opinion leader, attention was focused on the following:

- non-leaders will usually ask for advice from the opinion leader about the subject in question;

- opinion leaders will usually willingly give advice on their area of expertise;

- non-leaders will usually heed the advice of the opinion leader;

- non-leaders will usually spontaneously pass on the advice of the opinion leaders to other 'non-leader' friends or acquaintances;

- the opinion leader will most often be the logical problem solver for the issue in question;

- the opinion leader will be perceived to be knowledgeable about the subject in question, influential and efficient;

- the opinion leader will be perceived as offering advice upon which reliance can be placed;

Health and beauty aid products were chosen because they are consistently available both in pharmacies and in other store types such as supermarkets, cafes or general dealers. The influence of the pharmacist as an opinion leader can thus be exerted, even although subsequent purchases of the products may be made through food stores.

The specific products included in the study were headache remedies, sun protection products, toothbrushes, beauty shampoos and deodorants. By determining the extent to which the consumer is influenced by the pharmacist or pharmacy assistant in the decision to purchase these products, it was possible to establish the degree of opinion leadership by product category.

The decision to restrict the population to white, female consumers was based on the All Media and Products Survey (AMPS) (1984) which found these consumers to be the 'heavy users' of toiletries and health and beauty aid products.

Information was obtained by means of a questionnaire completed on a personal interview basis. Three different techniques were used in constructing the questionnaire, namely, Semantic Differential, Likert Scale and Verbal Rating Scale. The semantic differential was used to assess the image of the pharmacist and pharmacy assistant as perceived by the consumer. The Likert scale was used to identify how consumers perceived the advice of the pharmacist and pharmacy assistant. The Verbal Rating Scales were used to assess the perceived extent of influence of the pharmacist and pharmacy assistant on the decision-making process for health and beauty aid products.

Because it was both logistically difficult and expensive to adequately research consumer respondents on a national basis, a random sample of 251 white, female consumers was chosen from the Johannesburg Metropolitan area. This area was chosen because: (i) it represents a sizable portion of the health and beauty aid market; and (ii) it is a large single city representing a cross-section of the target population.

The pilot study detected a number of weaknesses in the questionnaire, as well as some terminology that the respondents did not understand. By correcting the questionnaire accordingly, more meaningful data were collected in the main study.

\section{Results}

Table 1 and Table 2 reflect the willingness with which

Table 1 The willingness with which advice was given by pharmacists

\begin{tabular}{|c|c|c|c|c|c|c|c|c|c|c|}
\hline & \multicolumn{2}{|c|}{ Headache remedies } & \multicolumn{2}{|c|}{ Tooth-brush } & \multicolumn{2}{|c|}{ Deodorant } & \multicolumn{2}{|c|}{$\begin{array}{l}\text { Sun protection } \\
\text { products }\end{array}$} & \multicolumn{2}{|c|}{ Beauty shampoos } \\
\hline & No & $\%$ & No & $\%$ & No & $\%$ & No & $\%$ & No & $\%$ \\
\hline Those who have had advice from a pharmacist & 120 & 47,8 & 14 & 5,6 & 11 & 4,4 & 56 & 22,3 & 17 & 6,8 \\
\hline Very willing & 107 & 42,6 & 12 & 4,8 & 10 & 4,0 & 50 & 19,9 & 13 & 5,2 \\
\hline Willing & 13 & 5,1 & 2 & 0,8 & 1 & 0,4 & 6 & 2,4 & 2 & 0,8 \\
\hline Reluctant & - & & - & & - & & - & & 1 & 0,4 \\
\hline Very reluctant & - & & - & & - & & - & & - & \\
\hline Cannot remember how willing & - & & - & & - & & - & & 1 & 0,4 \\
\hline Have not had advice from the pharmacist & 131 & 52,2 & 237 & 94,4 & 240 & 95,6 & 195 & 77,7 & 234 & 93,3 \\
\hline
\end{tabular}


Table 2 The willingness with which advice was given by pharmacy assistants

\begin{tabular}{|c|c|c|c|c|c|c|c|c|c|c|}
\hline & \multicolumn{2}{|c|}{ Headache remedies } & \multicolumn{2}{|c|}{ Tooth-brush } & \multicolumn{2}{|c|}{ Deodorant } & \multicolumn{2}{|c|}{$\begin{array}{l}\text { Sun protection } \\
\text { products }\end{array}$} & \multicolumn{2}{|c|}{ Beauty shampoos } \\
\hline & No & $\%$ & No & $\%$ & No & $\%$ & No & $\%$ & No & $\%$ \\
\hline Those who have had advice from a pharmacy assistant & 56 & 22,3 & 25 & 10,0 & 28 & 11,2 & 45 & 17,9 & 34 & 13,5 \\
\hline Very willing & 42 & 16,7 & 19 & 7,6 & 21 & 8,4 & 38 & 15,1 & 24 & 9,6 \\
\hline Willing & 12 & 4,8 & 6 & 2,4 & 7 & 2,8 & 7 & 2,8 & 9 & 3,6 \\
\hline Reluctant & - & & - & & - & & - & & 1 & 0,4 \\
\hline Very reluctant & - & & - & & - & & - & & - & \\
\hline Cannot remember how willing & 2 & 0,8 & - & & - & & - & & 1 & 0,4 \\
\hline Have not had advice from the pharmacy assistant & 195 & 77,7 & 226 & 90,0 & 223 & 88,8 & 206 & 82,1 & 217 & 86,5 \\
\hline
\end{tabular}

advice was given respectively by the pharmacist and the pharmacy assistant to the respondents in their purchase decisions for health and beauty products.

In Table 1 it can be seen that a high proportion of respondents $(47,8 \%)$ sought the advice of the pharmacist for the purchase of headache remedies, whereas Table 2 reveals that a relatively low proportion of respondents $(22,3 \%)$ sought the advice of the pharmacy assistant for the same product.

The extent to which advice was sought from pharmacists and pharmacy assistants for the purchase of the other four products reduces substantially. It is significant to note that for the purchase of the two products that are more for daily use, that is, the toothbrush and deodorant, the respondent was more likely to ask the advice of the pharmacy assistant than the pharmacist. This is probably because of the less technical nature of those products, the choice of which would tend to be more subjective. Put another way, this would be termed a low-involvement purchase which does not require complex purchase decision making. Hawkins, $e t$ al. (1983: 221) state that 'in a low-involvement purchase, one is not likely to seek an opinion leader'. This is typical of the purchase situation where there is a low degree of perceived risk on the part of the consumer.

The information contained in Table 1 and Table 2 tends to support the contention that opinion leadership is category specific and that advice is sought by the consumer in the area of pharmaceuticals in which the pharmacist is qualified.

With reference to Table 1 and Table 2 it is important to note that $89 \%$ of those receiving advice from a pharmacist and $75 \%$ receiving advice from a pharmacy assistant about the purchase of a headache remedy stated that the advice was given very willingly. In fact, over a range of 406 responses only two could not remember how willing the pharmacist was and only one thought that the pharmacy assistant was reluctant to give advice willingly. The willingness to give advice is an important characteristic of opinion leadership for which both the pharmacist and the pharmacy assistant qualify in this case.

Apart from headache remedies, no significance can be attached to the other products because of the small base of replies. There was, however, a positive response with regard to sun protection products which followed the pattern for headache remedies. This is perhaps not surprising, as sun protection products are more of a highinvolvement purchase requiring more complex decisionmaking processes than deodorants, beauty shampoos or tooth-brushes.

Once the consumer has been offered 'expert' advice, the key to deciding opinion leadership is the extent to which that advice is heeded.

Table 3 The extent to which the pharmacists' advice was heeded

\begin{tabular}{|c|c|c|c|c|c|c|c|c|c|c|}
\hline & \multicolumn{2}{|c|}{$\begin{array}{l}\text { Headache } \\
\text { remedies }\end{array}$} & \multicolumn{2}{|c|}{$\begin{array}{l}\text { Tooth- } \\
\text { brush }\end{array}$} & \multicolumn{2}{|c|}{ Deodorant } & \multicolumn{2}{|c|}{$\begin{array}{l}\text { Sun pro- } \\
\text { tection } \\
\text { products }\end{array}$} & \multicolumn{2}{|c|}{$\begin{array}{c}\text { Beauty } \\
\text { shampoos }\end{array}$} \\
\hline & No & $\%$ & No & $\%$ & No & $\%$ & No & $\%$ & No & $\%$ \\
\hline Almost always & 80 & 31,9 & 15 & 6,0 & 10 & 4,0 & 39 & 15,5 & 12 & 4,8 \\
\hline Often & 26 & 10,4 & 3 & 1,2 & 3 & 1,2 & 13 & 5,2 & 4 & 1,6 \\
\hline Seldom & 13 & 5,2 & 3 & 1,2 & 3 & 1,2 & 8 & 3,2 & 6 & 2,4 \\
\hline Never & 6 & 2,4 & 5 & 2,0 & 5 & 2,0 & 5 & 2,0 & 5 & 2,0 \\
\hline $\begin{array}{l}\text { Have not had } \\
\text { advice from }\end{array}$ & & & & & & & & & & \\
\hline the pharmacist & 125 & 50,2 & 225 & 89,6 & 230 & 91,6 & 186 & 74,1 & 224 & 89,2 \\
\hline
\end{tabular}

Table 4 The extent to which the pharmacy assistants' advice was heeded

\begin{tabular}{|c|c|c|c|c|c|c|c|c|c|c|}
\hline & \multicolumn{2}{|c|}{$\begin{array}{l}\text { Headache } \\
\text { remedies }\end{array}$} & \multicolumn{2}{|c|}{$\begin{array}{l}\text { Tooth- } \\
\text { brush }\end{array}$} & \multicolumn{2}{|c|}{ Deodorant } & \multicolumn{2}{|c|}{$\begin{array}{l}\text { Sun pro- } \\
\text { tection } \\
\text { products }\end{array}$} & \multicolumn{2}{|c|}{$\begin{array}{c}\text { Beauty } \\
\text { shampoos }\end{array}$} \\
\hline & No & $\%$ & No & $\%$ & No & $\%$ & No & $\%$ & No & $\%$ \\
\hline Almost & 25 & 10,0 & 17 & 6,8 & 13 & 5,2 & 20 & 8,0 & 17 & 6,8 \\
\hline Often & 20 & 8,0 & 11 & 4,4 & 16 & 6,4 & 21 & 8,4 & 20 & 8,0 \\
\hline Seldom & 23 & 9,2 & 9 & 3,6 & 12 & 4,8 & 16 & 6,4 & 13 & 5,2 \\
\hline Never & 19 & 7,6 & 15 & 6,0 & 17 & 6,8 & 15 & 6,0 & 17 & 6,8 \\
\hline $\begin{array}{l}\text { Have not had } \\
\text { advice from }\end{array}$ & & & & & & & & & & \\
\hline the pharmacist & 164 & 65,3 & 199 & 79,3 & 193 & 76,9 & 179 & 71,3 & 184 & 73,3 \\
\hline
\end{tabular}


Table 3 and Table 4 reveal that it was only for headache remedies and sun protection products that there was a positive response to the pharmacists' advice. For the other products, the majority of the respondents had not received advice from the pharmacist.

Of the 125 respondents who had received advice on headache remedies from the pharmacist, $64 \%$ claimed to heed the advice, 'almost always'. A further $20,8 \%$ would heed the pharmacist's advice 'often', making a total of $84,4 \%$ positive responses to the pharmacist's advice. The comparable statistic for sun protection products was $80 \%$ although this was off a lower base of 65 respondents.

Thus for those respondents who had received advice from a pharmacist, well over $80 \%$ heeded that advice indicating a high degree of opinion leadership. The response regarding the pharmacy assistant was, however, inconclusive.

The extent to which the advice offered by the pharmacist and pharmacy assistant was spontaneously passed on to others by the buyers of health and beauty and products, is reflected in Table 5 and Table 6.

The value of advice from opinion leaders can be measured by the extent to which that advice is passed spontaneously from one consumer to another. In Tables 5 and 6 it can be seen that in over $80 \%$ of cases, the advice received from the pharmacist was likely to be passed on, while, on average, in $50 \%$ of the cases the advice of the pharmacy assistant was likely to be passed on. Thus, the pharmacist again qualified as an opinion leader on this dimension while it was difficult to categorically judge the position of the pharmacy assistant.

In addressing the contention that the opinion leader will most often be the logical problem solver for problems falling within his area of expertise, respondents were asked to nominate the ideal person to whom they would turn for advice regarding the purchase of health and beauty aid products. The results are reflected in Table 7.

From the responses shown in Table 7 , the following

Table 5 The extent to which the advice of pharmacists was spontaneously passed on

\begin{tabular}{|c|c|c|c|c|c|c|c|c|c|c|}
\hline & \multicolumn{2}{|c|}{$\begin{array}{l}\text { Headache } \\
\text { remedies }\end{array}$} & \multicolumn{2}{|c|}{$\begin{array}{l}\text { Tooth- } \\
\text { brush }\end{array}$} & \multicolumn{2}{|c|}{ Deodorant } & \multicolumn{2}{|c|}{$\begin{array}{l}\text { Sun pro- } \\
\text { tection } \\
\text { products }\end{array}$} & \multicolumn{2}{|c|}{$\begin{array}{c}\text { Beauty } \\
\text { shampoos }\end{array}$} \\
\hline & No & $\%$ & No & $\%$ & No & $\%$ & No & $\%$ & No & $\%$ \\
\hline Almost always & 53 & 21,1 & 11 & 4,4 & 7 & 2,8 & 31 & 12,4 & 13 & 5,2 \\
\hline Often & 40 & 15,9 & 8 & 3,2 & 7 & 2,8 & 21 & 8,4 & 5 & 2,0 \\
\hline Seldom & 17 & 6,8 & 4 & 1,6 & 3 & 1,2 & 5 & 2,0 & 4 & 1,6 \\
\hline Never & 15 & 6,0 & 3 & 1,2 & 4 & 1,6 & 8 & 3,2 & 5 & 2,0 \\
\hline $\begin{array}{l}\text { Have not had } \\
\text { advice from }\end{array}$ & & & & & & & & & & \\
\hline the pharmacist & 126 & 50,2 & 225 & 89,6 & 230 & 91,6 & 186 & 74,1 & 224 & 89,2 \\
\hline
\end{tabular}

Table 6 The extent to which the advice of pharmacy assistants was spontaneously passed on

\begin{tabular}{|c|c|c|c|c|c|c|c|c|c|c|}
\hline & \multicolumn{2}{|c|}{$\begin{array}{r}\text { Headache } \\
\text { remedies }\end{array}$} & \multicolumn{2}{|c|}{$\begin{array}{l}\text { Tooth- } \\
\text { brush }\end{array}$} & \multicolumn{2}{|c|}{ Deodorant } & \multicolumn{2}{|c|}{$\begin{array}{l}\text { Sun pro- } \\
\text { tection } \\
\text { products }\end{array}$} & \multicolumn{2}{|c|}{$\begin{array}{l}\text { Beauty } \\
\text { shampoos }\end{array}$} \\
\hline & No & $\%$ & No & $\%$ & No & $\%$ & No & $\%$ & No & $\%$ \\
\hline Almost always & 20 & 8,0 & 15 & 6,0 & 14 & 5,6 & 16 & 6,4 & 17 & 6,8 \\
\hline Often & 28 & 11,1 & 11 & 4,4 & 14 & 5,6 & 25 & 10,0 & 22 & 8,8 \\
\hline Seldom & 17 & 6,8 & 10 & 4,0 & 10 & 4,0 & 9 & 3,6 & 13 & 5,2 \\
\hline Never & 22 & 8,8 & 16 & 6,4 & 20 & 8,0 & 22 & 8,8 & 15 & 6,0 \\
\hline $\begin{array}{l}\text { Have not had } \\
\text { advice from }\end{array}$ & & & & & & & & & & \\
\hline the pharmacist & 164 & 65,3 & 199 & 79,3 & 193 & 79,9 & 179 & 71,3 & 184 & 73,3 \\
\hline
\end{tabular}

Table 7 The ideal person for advice on the purchase of health and beauty aid products

\begin{tabular}{|c|c|c|c|c|c|c|c|c|c|c|c|c|}
\hline & \multicolumn{2}{|c|}{$\begin{array}{c}\text { Headache } \\
\text { remedies }\end{array}$} & \multicolumn{2}{|c|}{ Tooth-brush } & \multicolumn{2}{|c|}{ Deodorant } & \multicolumn{2}{|c|}{$\begin{array}{l}\text { Sun protection } \\
\text { products }\end{array}$} & \multicolumn{2}{|c|}{$\begin{array}{c}\text { Beauty } \\
\text { shampoos }\end{array}$} & \multicolumn{2}{|c|}{ Total } \\
\hline & No & $\%$ & No & $\%$ & No & $\%$ & No & $\%$ & No & $\%$ & No & $\%$ \\
\hline Doctor & 124 & 49,4 & & & 4 & 1,6 & 24 & 9,6 & 1 & 0,4 & 153 & 12,2 \\
\hline Pharmacist & 113 & 45,0 & 25 & 10,0 & 40 & 16,0 & 93 & 37,1 & 35 & 13,9 & 306 & 24,5 \\
\hline Pharmacy assistant & 1 & 0,4 & 10 & 4,0 & 22 & 8,8 & 19 & 7,6 & 21 & 8,4 & 73 & 5,8 \\
\hline Beauty consultant in pharmacy & - & - & - & - & 4 & 1,6 & 2 & 0,8 & 6 & 2,4 & 10 & 0,01 \\
\hline Friend/member of family & 2 & 0,8 & 5 & 2,0 & 38 & 15,1 & 20 & 8,0 & 13 & 5,2 & 78 & 6,2 \\
\hline Dermatologist & - & - & - & - & 5 & 2,0 & 19 & 7,6 & - & - & 24 & 1,9 \\
\hline Dentist & - & - & 155 & 61,8 & - & - & - & - & 2 & 0,8 & 157 & 12,6 \\
\hline Hairdresser & - & - & - & - & - & - & - & - & 80 & 33,1 & 80 & 6,4 \\
\hline Working colleague & - & - & - & - & 1 & 0,4 & 1 & 0,4 & - & - & 2 & 0,2 \\
\hline Other beauty consultants & - & - & - & - & 8 & 3,2 & 7 & 2,8 & 4 & 1,6 & 19 & 1,6 \\
\hline No-one & 9 & 3,6 & 52 & 20,7 & 127 & 50,6 & 54 & 21,5 & 83 & 33,1 & 325 & 26,0 \\
\hline Would never buy & 2 & 0,8 & 2 & 0,8 & 1 & 0,4 & 10 & 4,0 & 1 & 0,4 & 16 & 1,3 \\
\hline Advertising & - & - & 2 & 0,8 & 1 & 0,4 & 2 & 0,8 & 2 & 0,8 & 7 & 0,5 \\
\hline
\end{tabular}


observations can be made: In terms of total responses, the pharmacist achieved the highest score $(24,5 \%)$ as the ideal person to turn to when seeking advice on the purchase of health and beauty aid products in general. Because of the low perceived risk associated with the purchase and consumption of many products in the health and beauty aid category, it is not surprising that $26 \%$ of responses reflected that 'no-one' was needed for advice on the purchase of the general category of products under examination. The glaring exception to this was, however, headache remedies where the doctor and the pharmacist together accounted for $94,4 \%$ of responses as the ideal person for advice. Of the total of $94,4 \%$ of responses, the pharmacist accounted for $45 \%$.

With regard to the sun-protection category, it is significant to note that the pharmacist was rated ahead of the dermatologist for advice on sun protection products. This is probably attributable to the overall availability and accessibility of the pharmacist versus the other options. This is an important characteristic of opinion leadership as discussed earlier.

The pharmacy assistant gained a rating of $5,8 \%$ of the total responses, indicating the respondents' preference for making use of more qualified options such as doctors, pharmacists and dermatologists.
In summary, the position of the pharmicist as the 'ideal' person from whom to seek advice is clearly one of opinion leader and although the pharmacy assistants achieved support for the sun protection, deodorant and beauty shampoo categories, they did not enjoy general appeal.

In addressing the proposition that the opinion leader will be perceived to be influential, efficient and knowledgeable about issues falling within his domain, use was made of the semantic differential technique with respondents being asked to rate the pharmacist and pharmacy assistant along several dimensions. The results are displayed in Table 8 and Table 9.

Table 8 reveals a high rating for the pharmacist as an opinion leader with the 'extremely' positive description achieving the highest score by a wide margin along almost every dimension. The exception was the 'knowledge in beauty matters' dimension, which while being positive in total, had the highest number of responses in the 'indifferent' description category.

Table 9 reveals that the pharmacy assistant also received a positive rating, although not to the same extent as the pharmacist. Of significance was the high rating on the efficiency and knowledge of 'beauty' and 'general matters' dimensions.

Table 8 Profile of the pharmacist

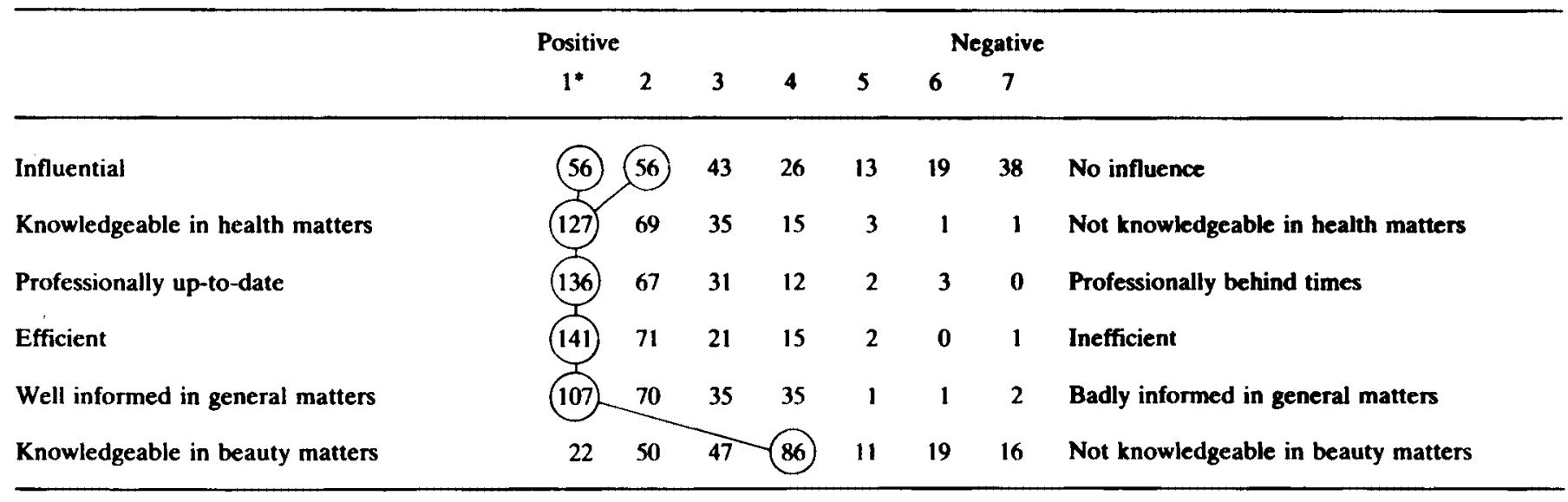

$1^{*}=$ Extremely positive; $2=$ Very positive; $3=$ Somewhat positive; $4=$ Indifferent; $5=$ Somewhat negative; $6=$ Very negative; $7=$ Extremely negative

Table 9 Profile of the pharmacy assistant

\begin{tabular}{lcccccccc}
\hline & Positive & \multicolumn{5}{c}{ Negative } \\
& $1^{*}$ & 2 & 3 & 4 & 5 & 6 & 7 & No influence \\
\hline Influential & 27 & 40 & 40 & 51 & 23 & 23 & 47 & Not knowledgeable in health matters \\
Knowledgeable in health matters & 30 & 28 & 62 & 56 & 26 & 22 & 27 & Profsionally behind times \\
Professionally up-to-date & 44 & 56 & 55 & 65 & 16 & 8 & 7 & Profession \\
Efficient & 91 & 69 & 48 & 29 & 10 & 2 & 2 & Inefficient \\
Well informed in general matters & 46 & 65 & 51 & 65 & 10 & 7 & 7 & Badly informed in general matters \\
Knowledgeable in beauty matters & 47 & 72 & 53 & 56 & 8 & 8 & 7 & Not knowledgeable in beauty matters \\
\hline
\end{tabular}

$1^{*}=$ Extremely positive; $2=$ Very positive; $3=$ Somewhat positive; $4=$ Indifferent; $5=$ Somewhat negative; $6=$ Very negative; $7=$ Extremely negative 
Table 10 The image of the pharmacist as an advisor or storekeeper
The pharmacist

gives sound

advice that

can be relied

upon

$\begin{array}{llllllllll}7 & 2,8 & 3 & 1,2 & 17 & 6,8 & 132 & 52,6 & 92 & 36,6\end{array}$

The pharmacist

is no more

than a

storekeeper

$\begin{array}{llllllllll}132 & 52,6 & 99 & 39,4 & 7 & 2,8 & 12 & 4,8 & 1 & 0,4\end{array}$

Table 11 The image of the pharmacy assistant as an advisor or counter assistant

\begin{tabular}{|c|c|c|c|c|c|c|c|c|c|c|}
\hline & $\begin{array}{l}\text { Stror } \\
\text { disag }\end{array}$ & $\begin{array}{l}\text { ngly } \\
\text { gree }\end{array}$ & Dise & gree & $\begin{array}{l}\text { Nei } \\
\text { agre } \\
\text { disa }\end{array}$ & $\begin{array}{l}\text { ther } \\
\text { e nor } \\
\text { gree }\end{array}$ & & gree & & $\begin{array}{l}\text { ongly } \\
\text { ree }\end{array}$ \\
\hline & No & $\%$ & No & $\%$ & No & $\%$ & No & $\%$ & No & $\%$ \\
\hline $\begin{array}{l}\text { The pharmacy } \\
\text { assistant gives } \\
\text { sound advice } \\
\text { that can be } \\
\text { relied upon } \\
\text { The pharmacy } \\
\text { assistant is no } \\
\text { more than a } \\
\text { counter assistant }\end{array}$ & 22 & 3,2 & 31 & 12,4 & 98 & 39,0 & 94 & 37,5 & 20 & 7,9 \\
\hline
\end{tabular}

Thus in terms of perceived professionalism, both the pharmacist and pharmacy assistant qualified as opinion leaders.

In addressing the contention that the opinion leader will be perceived as offering advice upon which reliance can be placed, a Likert-type scale was used to measure the extent to which the respondents agreed with two statements. The results are reflected in Table 10 and Table 11.

From the data in Table 10 it can be concluded that the pharmacist clearly possesses credibility among the respondents with only $4 \%$ doubting the soundness of his advice. There was a strong objection to the notion that the pharmacist was 'no more than a storekeeper' with $52,6 \%$ 'strongly disagreeing' and 39,4\% 'disagreeing' a total of $92 \%$.

Table 11 reveals that the pharmacy assistant did not rate as highly as the pharmacist although a total of only $15,6 \%$ of the respondents doubted the advice of pharmacy assistants. $48,2 \%$ of respondents disagreed that the pharmacy assistant was 'no more than a counter assistant'. This, however, was largely counterbalanced by $35,5 \%$ of respondents who agreed that the pharmacy assistant was 'no more than a counter assistant'.

The respondents clearly valued the advice of both the pharmacist and the pharmacy assistant and saw them both as more than storekeepers and counter assistants respectively, although the weight of support was overwhelmingly behind the pharmacist.

\section{Conclusions}

The empirical evidence suggests an overwhelmingly positive perception of the pharmacist as an opinion leader by the respondents. This is particularly significant in the recommendation of professional and ethical products. The pharmacist qualifies as an opinion leader based on the empirical evidence discussed in detail in the previous sections. This is according to the following characteristics:

1. He is accustomed to being asked advice about health and beauty aid products.

2. He is perceived to be well qualified.

3. His advice is heeded by the majority of respondents.

4. He is perceived to be giving his advice willingly.

5. The respondent is likely to pass on his advice to other consumers.

6. The pharmacist is rated as the ideal person from whom to ask advice for the purchase of health and beauty aid products.

7. The pharmacist is perceived to be extremely knowledgeable, efficient, professionally up-to-date and influential.

8. The pharmacist is perceived to offer sound advice.

It is concluded therefore, that the pharmacist qualifies as an opinion leader on these dimensions, particularly with regard to those health and beauty aid products where the level of perceived risk is high.

The position of the pharmacy assistant, however, is not as clear as that of the pharmacist. On the positive side, the respondents had the following perceptions:

1. A reasonably high proportion of respondents $(22,3 \%)$ sought advice from the pharmacy assistant for the purchase of headache remedies.

2. The pharmacy assistant rated relatively higher than the pharmacist on product groups such as toothbrushes and deodorants.

3. The pharmacy assistant is extremely accessible.

4. The pharmacy assistant willingly gives advice.

5. The pharmacy assistant is perceived to be knowledgeable, efficient, well informed and professionally up-to-date.

6. The respondents' perception was that the pharmacy assistant's advice was generally sound.

The following perceptions by the respondents require further comment, however, before concluding whether the pharmacy assistant qualifies as an opinion leader:

a. The respondents were divided in their heeding and passing on of the pharmacy assistant's advice. Certainly, the pharmacy assistant did not rate as well as the pharmacist but in absolute terms the 
respondents who received advice from a pharmacy assistant would heed the advice or pass it on, in $\mathbf{5 0 \%}$ of cases.

Based on this and the evidence in the previous sections, it is concluded that the empirical evidence weighs in favour of the pharmacy assistant being regarded as an opinion leader. The fact that the pharmacy assistant is very accessible to the general public contributes significantly to this conclusion.

b. The pharmacy assistant did not achieve a high score as the ideal person from whom the respondents would seek advice. The respondents would be more likely to consult a better qualified person such as the pharmacist or a doctor, given that the ideal situation exists where these persons are easily accessible. The fact that these professions were chosen ahead of the pharmacy assistant, however, does not rule the latter out as an opinion leader.

The overriding conclusion is that the pharmacist and pharmacy assistant are important marketing tools for the marketers of health and beauty aid products. This conclusion is underlined by Meyer \& Vassilatos (1983: 704) who came to a similar conclusion in their study from the pharmacist's point of view: 'The retail pharmacist has not yet realized the full extent of, or achieved to full capacity, his professional role. Inadequate communication and some misconceptions on the part of the public seem to be strong contributing factors to the full professional potential of the pharmacist not being tapped'.

In view of this study and the importance of both the pharmacist and pharmacy assistant in the eyes of the consumer, the marketers of health and beauty aid products would be well advised to ensure that their products are well known by the pharmacist and pharmacy assistant.

\section{Implications of the research}

These research findings have important implications for the marketers of health and beauty aid products, as well as for pharmacists themselves.

Implications for the marketer of heatth and beauty aid products

The research produced some interesting implications for the organization which markets products to the consumer through pharmacy outlets. These are summarized as follows:

(i) Many marketing organizations neglect an important and potentially powerful force in the dissemination of good product information about their products by not making the pharmacist knowledgeable about their brands and by not keeping the pharmacist up-to-date.

(ii) An opportunity exists to make greater use of the pharmacy assistant in the dissemination of product information by keeping the pharmacy assistant aware and updated on relevant product information. (iii) An opportunity exists to stimulate the opinion leadership position of the pharmacist by using the pharmacist to tacitly endorse products with slogans such as, 'Your pharmacist can tell you more about ...' and, 'Ask your pharmacist about ...'

(iv) Based on the evidence in the research, consideration should be given to selling analgesics and sun protection products on a 'pharmacy-only' basis even where a wider distribution in food stores is possible. This is to capitalize on the consumer's preference for asking advice from the pharmacist on these two product categories.

(v) An opportunity exists to position the pharmacy assistant as a beauty and daily hygiene consultant. This is because the consumer both respects the advice of the pharmacy assistant and tends to seek advice from her on these product categories.

(vi) Greater use can be made of journals which are directed at pharmacists and pharmacy assistants in order to communicate product information.

(vii) The supermarket remains an important distribution outlet particularly for products where there is little perceived risk in the purchase decision. This applies to products of a daily hygiene nature such as beauty shampoos and tooth-brushes.

\section{Implications for the pharmacist}

(i) If the pharmacist perceives a trade-off in his role as either 'junior doctor' or 'storekeeper', this research confirms the value the consumer places on the pharmacist as opinion leader in the former role.

(ii) The pharmacist needs to capitalize on that strength and encourage the consumer to visit him for advice. This will create additional traffic through the pharmacy.

(iii) The pharmacist could exploit the perception by the consumer of the value of the advice of the pharmacy assistant. This could be done by employing high calibre staff who are appropriately trained and motivated. This will encourage customers to come to the pharmacy for advice from the pharmacy assistants, thereby creating more traffic through the pharmacy.

(iv) The pharmacist needs to capitalize on his role as health care advisor, as well as his accessibility, by continuing to provide spontaneous pharmaceutical and health care advice to his customers. This is against a trend where the pharmacist is tending to withdraw from the front of the pharmacy into the dispensary. It is vital to the continuing existence of pharmacies that the pharmacist remains accessible to the public.

(v) In addition to (iv) above, the pharmacist should encourage the consumer to seek his advice by dealing with questions and enquiries courteously and in a helpful manner. The pharmacist should avoid treating questions as having a high 'nuisance value' and as being a waste of time. 


\section{References}

All Media and Products Survey, 1984. SA Advertising Research Foundation, Johannesburg.

Engel, J.F., Blackwell, R.D. \& Kollat, D.J. 1978. Consumer Behaviour.insdale, Illinois: Dryden Press.

Foxall, G.R. 1980. Consumer Behaviour. London: Croom Helm.

Glock, C.Y. \& Nicosia, F.M. 1983. Sociology and the Study of Consumers. J. Advert. Res. vol. 3.

Hawkins, D.I., Best, R.J. \& Coney, K.A. 1983. Consumer • Behaviour: Implications for Market Strategy. Plano, Texas: Business Publications.

Kassarjian, H.H. \& Robertson, T.S. 1973. Perspectives in Consumer Behaviour. Illinois: Scott Foresman and Co.

Loudon, D.L. \& Della Bitta, A.J. 1979. Consumer Behaviour: Concepts and Applications USA: McGraw-Hill.
Meyer, G. \& Vassilatos, C. 1983. The retail Pharmacist: Professional or Shopkeeper? SA Pharm. J., vol.48.

Nel, E.M. 1982. Attitudes Towards Pharmacy. SA Pharm. J., vol. 48.

Ross, I. 1975. Perceived Risk and Consumer Behaviour: A Critical Review. Advances in Consumer Research, vol.2.

Schiffman, L.G. \& Kanuk, L.L. 1978. Consumer Behaviour. Englewood Cliffs: Prentice-Hall.

Sternthal, B. \& Craig, C.S. 1982. Consumer behaviour: An Information Processing Perspective. Englewood Cliffs: Prentice-Hall.

Walters, C.G. \& Paul, G.W. 1970. Consumer Behaviour: Basic Findings and Management Implications. USA, John Wiley.

Zaltman, G. \& Wallendorf, M. 1983. Consumer Behaviour: Basic Findings and Management Implications. USA, John Wiley. 